\title{
Taxol $^{\circledR}$ Separation in a Simulated Moving Bed
}

\author{
Marco Aurelio Cremasco \\ Chemical Engineering School/University of Campinas
}

Brazil

\section{Introduction}

Cancer is a public health concern worldwide that must be considered in various area of the knowledge. In USA, appear a million cases each year. In the South East of the Brazil, cancer is the second largest cause of death. The introduction of chemotherapy to combat the cancer results in significant tumors cure that didn't control with success by exclusive use of surgery and/or radiotherapy (Bonadonna, 1990). Researchers around the world have particular attention in the study of natural products as possible source of antineoplasic agents. Due to the diversity of the chemical structures founded in theses products, there are big chances to identify news molecules with anti-tumor activities (Cremasco \& Starquit, 2010). The Taxol® (commercial name for Paclitaxel) discovery offers good points for this reasoning (Holanda et al., 2008).

According to Rhoads (1995), while many drugs act to disrupt the cancer cells, Taxol ${ }^{\circledR}$ paralyzes the internal structure. In the metaphase stage of cell replication, chromosome pairs split and move to the opposite ends of the cell and wait to become part of a daughter cell. Rhoads (1995) reported that these chromosomes were guided by the microtubules made of tubulin. These bundles of microtubules must be dismantled before the cell be divided. However, Taxol ${ }^{\circledR}$ prevents the cells from dividing further and essentially halts the cancer growth. It has been approved by the FDA, in the USA, for the treatment of advanced breast cancer, lung cancer, and refractory ovarian cancer. Taxol ${ }^{\circledR}$ is a diterpene compound (Figure 1).

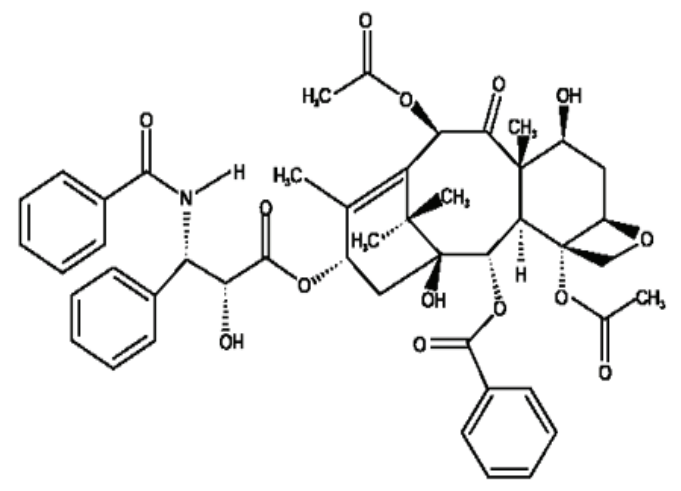

Fig. 1. Chemical structure of Taxol® 
Taxol ${ }^{\circledR}$ is an extremely hydrophobic molecule. Its low solubility in water makes the administration of the drug difficult. The complexity of Taxol ${ }^{\circledR}$ rests primarily in its stereochemistry, which makes organic synthesis extremely difficult $(\mathrm{Wu}, 1999)$. Taxol ${ }^{\circ}$ can be isolated from the bark of the Pacific yew (Taxus brevifolia). It also can be produced and recovered from the plant tissue culture (PTC) broth (Srinivasan, 1994). The presence of a number of structurally similar compounds in the source material for Taxol®, such as cephalomannine and baccatin, complicates the recovery and purification process $(\mathrm{Wu}, 1999)$. A major portion of the purification cost is due to the separation of Taxol ${ }^{\circledR}$ from a large number of taxanes with similar molecular structures. In this case, Taxol ${ }^{\circ}$ separation and purification usually involves extraction, solvent portioning, and preparative HPLC purification to eliminate the hazardous solvents and the expense associated with pressure equipment (Wu, 1999). Conventional batch chromatography has been used for Taxol® separation from PTC broth (Wu et al., 1997). This technique, however, is expensive and has low yield and low productivity. A simulated moving bed (SMB), which saves solvent and increases the adsorbent utilization (Borges da Silva et al., 2006), can result in a more economical separation process. In a traditional SMB system, a series of fixed bed columns is connected to form a circuit (Figure 2).

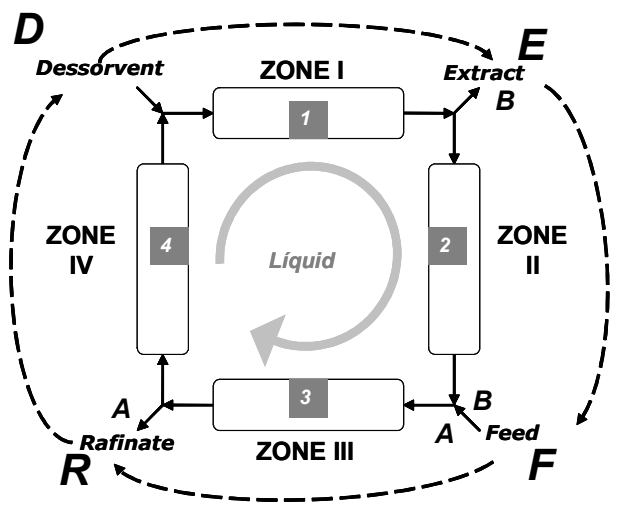

Fig. 2. Classical four zones SMB system (Cremasco \& Starquit, 2010)

This circuit is divided into four zones by two inlet ports (feed and a solvent) and two outlet ports (a raffinate port, where the low-affinity mixture A is removed, and an extract port, where a high-affinity mixture B is removed). The inlet and outlet ports are periodically moved along the solvent flow direction by multiple-position valves, causing an apparent countercurrent movement between the liquid and the solid phase. As in batch chromatography, mixture A migrates faster than mixture B in the liquid flow direction (Ma \& Wang, 1997). If the average feed port velocity is lower than the mixture A migration velocity and larger than mixture B migration velocity, then A will have a net velocity in the solvent flow direction relative to the feed port, while B will have a net velocity in the opposite direction. In this case, the standing wave approach says that mixture A adsorption wave remains stationary in zone IV, while its desorption wave stands in zone II. Solute B adsorption wave lies in zone III, adsorption wave lies in zone III, and its desorption wave stands in zone I (Ma \& Wang, 1997). Figure 3 represents the standing wave approach for multicomponent system. In this figure, A, means low-affinity mixture; B, high-affinity 
mixture; D means solvent flow; E, extract flow; F, feed flow; and R, raffinate flow (Cremasco \& Starquit, 2010).

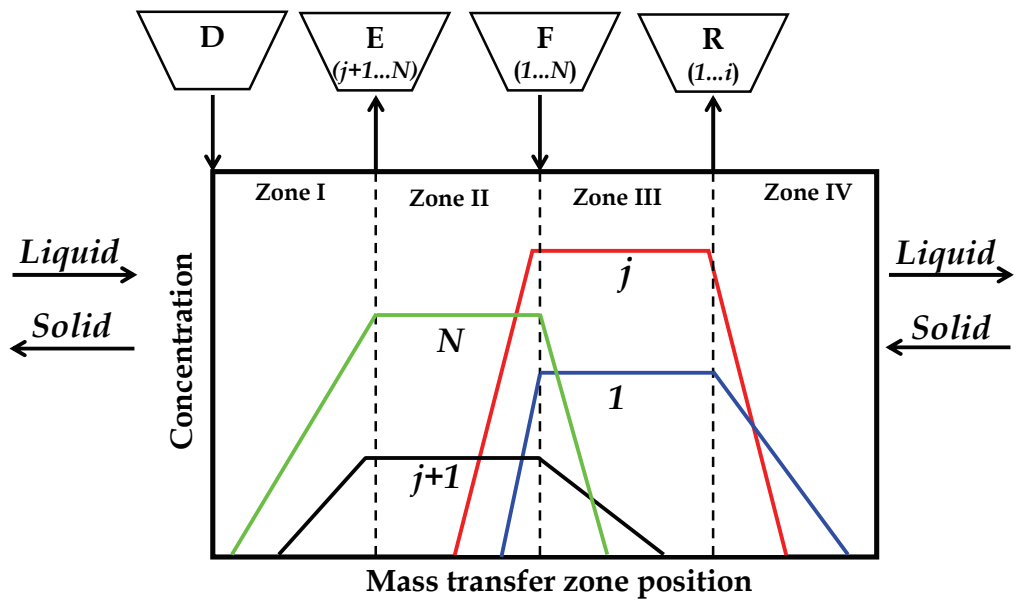

Fig. 3. Standing wave theory, non-equilibrium model (Cremasco et al., 2009a)

\section{Theory}

\subsection{Standing wave analysis}

For a system of $N$ components in which the components are numbered from low to high affinity as $1, \ldots, j, j+1, \ldots, N$ (Figure 3 ); and in which a split is desired between component $j$ and $j+1$, the standing wave equation are as follows (Cremasco et al., 2009a):

$$
\begin{aligned}
& u^{I}-\left(1+\psi \delta_{N}\right) \frac{L}{v}=-\beta_{N}^{I}\left(\frac{E_{b_{N}}^{I}}{L^{I}}+\frac{\psi v^{2} \delta_{N}^{2}}{L^{I} K_{f_{N}}^{I}}\right)=B_{N}^{I} \\
& u^{I I}-\left(1+\psi \delta_{j}\right) \frac{L}{v}=\beta_{j}^{I I}\left(\frac{E_{b_{j}}^{I I}}{L^{I I}}+\frac{\psi v^{2} \delta_{j}^{2}}{L^{I I} K_{f_{j}}^{I I}}\right)=B_{j}^{I I} \\
& u^{\text {III }}-\left(1+\psi \delta_{j+1}\right) \frac{L}{v}=-\beta_{j+1}^{I I I}\left(\frac{E_{b_{j+1}}^{I I I}}{L^{I I I}}+\frac{\psi v^{2} \delta_{j+1}^{2}}{L^{I I I} K_{f_{j+1}}^{I I I}}\right)=B_{j+1}^{I I I} \\
& \mathrm{u}^{\mathrm{IV}}-\left(1+\psi \delta_{1}\right) \frac{\mathrm{L}}{\mathrm{v}}=-\beta_{1}^{\mathrm{IV}}\left(\frac{\mathrm{E}_{\mathrm{b}_{1}}^{\mathrm{IV}}}{\mathrm{L}^{\mathrm{IV}}}+\frac{\psi \mathrm{v}^{2} \delta_{1}^{2}}{\mathrm{~L}^{\mathrm{IV}} \mathrm{K}_{\mathrm{f}_{1}}^{\mathrm{IV}}}\right)=\mathrm{B}_{1}^{\mathrm{IV}}
\end{aligned}
$$

with:

$$
\psi=\frac{1-\varepsilon}{\varepsilon}
$$




$$
\delta_{\mathrm{j}}=\varepsilon_{\mathrm{p}}+\left(1-\varepsilon_{\mathrm{p}}\right) \mathrm{k}_{\mathrm{pj}}
$$

To obtain the for port movement velocity, $\mathrm{v}$, it is necessary to consider the dead volume from tubes that connect the columns, for example. This time is defined by

$$
\mathrm{t}_{\mathrm{p}}=\frac{\mathrm{L}}{\mathrm{V}}+\mathrm{t}_{0}
$$

$\mathrm{L}$ is mass transfer zone length (assume equal column effective length), $t_{0}$ is dead time in mass transfer zone $\mathrm{k}$ from

$$
\mathrm{t}_{0}=\frac{\mathrm{V}_{0}^{\mathrm{k}}}{\varepsilon \mathrm{u}^{\mathrm{k}} \mathrm{A}}
$$

where $V_{0}^{k}$ is dead volume in zone k. $A$ is cross sectional column area; $u^{k}$, is the liquid interstitial velocity in zone k. From Figure 2

$$
u^{\mathrm{III}}-\mathrm{u}^{\mathrm{I}}=\mathrm{u}_{\mathrm{F}}
$$

If one substitutes Eqs. (2) and (3) into Eq. (8), its results

$$
\mathrm{t}_{\mathrm{p}}^{2}-\mathrm{bt} \mathrm{p}_{\mathrm{p}}+\mathrm{c}=0
$$

with

$$
\begin{gathered}
\mathrm{b}=\mathrm{t}_{0}^{\mathrm{III}}+\mathrm{t}_{0}^{\mathrm{II}}+\frac{\psi\left(\delta_{\mathrm{j}+1}-\delta_{\mathrm{j}}\right) \mathrm{L}}{\mathrm{u}_{\mathrm{F}}-\mathrm{B}_{\mathrm{j}+1}+\mathrm{B}_{\mathrm{j}}} \\
\mathrm{c}=\mathrm{t}_{0}^{\mathrm{III}} \times \mathrm{t}_{0}^{\mathrm{II}}+\frac{\mathrm{t}_{0}^{\mathrm{II}}\left(1+\psi \delta_{\mathrm{j}+1}\right) \mathrm{L}-\mathrm{t}_{0}^{\mathrm{III}}\left(1+\psi \delta_{j}\right) \mathrm{L}}{\mathrm{u}_{\mathrm{F}}-\mathrm{B}_{\mathrm{j}+1}+\mathrm{B}_{\mathrm{j}}}
\end{gathered}
$$

The $\beta$ values are determined from a pseudo-binary model, in which mixtures $A$ and $B$ are treated as single solutes A and B (Cremasco \& Starquit, 2010). The four $\beta$ values can be estimated from simple material balances around zones and mixing points. The following assumptions are made: (i) the concentration of solute A at the outlet of zone III is equal to its concentration at the raffinate port; (ii) the concentration of solute B at the inlet of zone II is equal to its concentration at the extract port; (iii) the ratio between the highest and the lowest concentrations for mixture (A or B) is the same in both adsorption and desorption zones. These assumptions lead to the following expressions:

$$
\begin{aligned}
& \beta_{1}^{\mathrm{IV}}=\ln \left(\frac{\mathrm{C}_{\mathrm{A}}^{\mathrm{R}} \mathrm{u}^{\mathrm{III}}-\mathrm{C}_{\mathrm{A}}^{\mathrm{F}} \mathrm{u}_{\mathrm{F}}}{\mathrm{u}^{\mathrm{II}} \mathrm{C}_{\mathrm{A}}^{\mathrm{E}}}\right)=\beta_{j}^{\mathrm{II}} \\
& \beta_{\mathrm{N}}^{\mathrm{I}}=\ln \left(\frac{\mathrm{C}_{\mathrm{B}}^{\mathrm{E}} \mathrm{u}^{\mathrm{II}}+\mathrm{C}_{\mathrm{B}}^{\mathrm{F}} \mathrm{u}_{\mathrm{F}}}{\mathrm{u}^{\mathrm{III}} \mathrm{C}_{\mathrm{B}}^{\mathrm{R}}}\right)=\beta_{\mathrm{j}+1}^{\mathrm{III}}
\end{aligned}
$$

in which, in the pseudo-binary model (Cremasco \& Wang, 2000), 


$$
\begin{aligned}
& C_{A}^{F}=\sum_{i=1}^{i=j} C_{i}^{F} \\
& C_{B}^{F}=\sum_{i=j+1}^{i=N} C_{i}^{F} \\
& C_{A}^{R}=\sum_{i=1}^{i=j} C_{i}^{R} \\
& C_{B}^{E}=\sum_{i=j+1}^{i=N} C_{i}^{E}
\end{aligned}
$$

The A and B mixture recoveries at the outlet ports are defined as

$$
\begin{gathered}
Y_{A}^{\text {mix }}=\frac{u_{R} C_{A}^{R}}{u_{F} C_{A}^{F}} \\
Y_{B}^{\text {mix }}=\frac{u_{E} C_{B}^{E}}{u_{F} C_{B}^{F}}
\end{gathered}
$$

$u_{R} \equiv R /(\varepsilon A)$ and $u_{E} \equiv E /(\varepsilon A)$ are the equivalent raffinate and extract interstitial velocities. Mass balances for mixtures $A$ and $B$ are substituted into Eqs. (12) and (13) to give

$$
\beta_{1}^{\mathrm{IV}}=\beta_{\mathrm{j}}^{\mathrm{II}}=\ell \mathrm{n}\left\{\left(\frac{\mathrm{u}_{\mathrm{E}}}{\mathrm{u}^{\mathrm{II}}}\right)\left(1-\mathrm{Y}_{\mathrm{A}}^{\mathrm{mix}}\right)^{-1}\left[\left(\frac{\mathrm{u}^{\mathrm{III}}}{\mathrm{u}_{\mathrm{R}}}\right) \mathrm{Y}_{\mathrm{A}}^{\mathrm{mix}}-1\right]\right\}
$$

and

$$
\beta_{\mathrm{N}}^{\mathrm{I}}=\beta_{\mathrm{j}+1}^{\mathrm{III}}=\ln \left\{\left(\frac{\mathrm{u}_{\mathrm{R}}}{\mathrm{u}^{\mathrm{III}}}\right)\left(1-\mathrm{Y}_{\mathrm{B}}^{\mathrm{mix}}\right)^{-1}\left[\left(\frac{\mathrm{u}^{\mathrm{II}}}{\mathrm{u}_{\mathrm{E}}}\right) Y_{\mathrm{B}}^{\text {mix }}+1\right]\right\}
$$

Substituting Eqs. (20) and (21) into (1) through (4), one obtains

$$
\begin{aligned}
& \mathrm{u}^{\mathrm{I}}-\left(1+\psi \delta_{N}\right) \frac{\mathrm{L}}{\mathrm{v}}=\ell \mathrm{n}\left\{\left(\frac{\mathrm{u}_{\mathrm{R}}}{\mathrm{u}^{\mathrm{III}}}\right)\left(1-\mathrm{Y}_{\mathrm{B}}^{\text {mix }}\right)^{-1}\left[\left(\frac{\mathrm{u}^{\mathrm{II}}}{\mathrm{u}_{\mathrm{E}}}\right) \mathrm{Y}_{\mathrm{B}}^{\text {mix }}+1\right]\right\}\left(\frac{\mathrm{E}_{\mathrm{b}_{\mathrm{N}}}^{\mathrm{I}}}{\mathrm{L}^{\mathrm{I}}}+\frac{\psi \mathrm{v}^{2} \delta_{N}^{2}}{\mathrm{~L}^{\mathrm{I}} \mathrm{K}_{\mathrm{f}_{\mathrm{N}}}^{\mathrm{I}}}\right)=\mathrm{B}_{\mathrm{N}}^{\mathrm{I}} \\
& u^{I I}-\left(1+\psi \delta_{j}\right) \frac{L}{v}=\ln \left\{\left(\frac{u_{E}}{u^{I I}}\right)\left(1-Y_{A}^{\text {mix }}\right)^{-1}\left[\left(\frac{u^{I I I}}{u_{R}}\right) Y_{A}^{m i x}-1\right]\right\}\left(\frac{E_{b_{j}}^{I I}}{L^{I I}}+\frac{\psi v^{2} \delta_{j}^{2}}{L^{I I} K_{f_{j}}^{I I}}\right)=B_{j}{ }^{I I}
\end{aligned}
$$

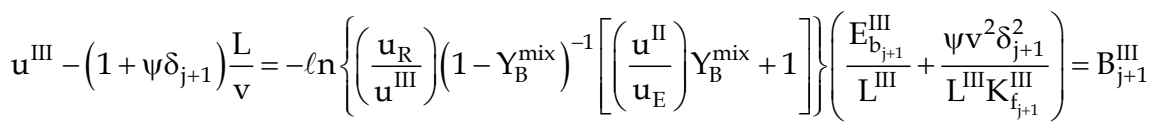

$$
\begin{aligned}
& \mathrm{u}^{\mathrm{IV}}-\left(1+\psi \delta_{1}\right) \frac{\mathrm{L}}{\mathrm{v}}=-\ell \mathrm{n}\left\{\left(\frac{\mathrm{u}_{\mathrm{E}}}{\mathrm{u}^{\mathrm{II}}}\right)\left(1-\mathrm{Y}_{\mathrm{A}}^{\mathrm{mix}}\right)^{-1}\left[\left(\frac{\mathrm{u}^{\mathrm{III}}}{\mathrm{u}_{\mathrm{R}}}\right) \mathrm{Y}_{\mathrm{A}}^{\mathrm{mix}}-1\right]\right\}\left(\frac{\mathrm{E}_{\mathrm{b}_{1}}^{\mathrm{IV}}}{\mathrm{L}^{\mathrm{IV}}}+\frac{\psi \mathrm{v}^{2} \delta_{1}^{2}}{\mathrm{~L}^{\mathrm{IV}} \mathrm{K}_{\mathrm{f}_{1}}^{\mathrm{IV}}}\right)=\mathrm{B}_{1}^{\mathrm{IV}}
\end{aligned}
$$


In order to obtain the flow rates and the switching time for LMS, the linear standing wave analysis was used by following steps:

1. Find column and particle characteristics $\left(D_{b}, L, V_{0}, \varepsilon, \varepsilon_{p}, d_{p}\right)$.

2. Find the partition coefficient $k_{p}$ (linear isotherm) for each solute and identify the lessretained mixture $A=1, \ldots, j$ and the more-retained mixture $B=j+1, \ldots, N$.

3. Find rate parameters $\left(D_{A B}, D_{p}, k_{f}, E_{b}\right)$. These constants can be from experimental data or from correlations founded in Literature. The values of $k_{f}$ and $E_{b}$ depend on the flow rate in zone k. The parameters associated with the corrections for mass-transfer effects, given in Eqs. (23) to (26) can be calculated from (Ma et al., 1996)

$$
\frac{1}{\mathrm{~K}_{\mathrm{f}_{\mathrm{j}}}^{\mathrm{k}}}=\frac{\mathrm{d}_{\mathrm{p}}}{6 \mathrm{k}_{\mathrm{f}_{\mathrm{j}}}^{\mathrm{k}}}+\frac{\mathrm{d}_{\mathrm{p}}^{2}}{60 \varepsilon_{\mathrm{P}} \mathrm{D}_{\mathrm{p}_{\mathrm{j}}}}
$$

4. Fix the feed concentrations $C_{A}{ }^{F}$ and $C_{B}{ }^{F}$.

5. Fix the mixture A yield at the raffinate port $\left(Y_{A}^{\text {mix }}\right)$ and the mixture $B$ yield at the extract port $\left(Y_{B}^{\text {mix }}\right)$.

6. Choose a feed flow rate $F$.

7. Calculate the liquid apparent interstitial velocity in each zone and simulated adsorbent velocity using Eqs. (22) to (25), assuming $B_{1}=B_{j}=B_{j+1}=B_{N}=0$.

8. Calculate the flow-rate values dependent on mass transfer parameters using the velocities from step 6 and the information in step 3.

9. Calculate the new liquid apparent interstitial velocity in each zone $k$, and simulated adsorbent velocity.

10. Calculate the convergence criteria given by

$$
\left[\sum_{\mathrm{k}=1}^{\mathrm{k}=4}\left(\mathrm{u}_{\mathrm{m}}^{\mathrm{k}}-\mathrm{u}_{\mathrm{m}-1}^{\mathrm{k}}\right)^{2}+\left(\mathrm{v}_{\mathrm{m}}-\mathrm{v}_{\mathrm{m}-1}\right)^{2}\right]^{1 / 2} \leq 0.1 \times 10^{-5}
$$

$m$ is the iteration number, and $k$ is the zone number.

11. To find zone flow rates and port switching time.

Notice that this strategy is directly applied for a binary mixture or for multicomponent mixture when the key-component for separation presents higher or lower affinity with sorbent when compared with other components in mixture. In case of key-component, in multicomponent mixture, that presents intermediary affinity (such as Taxol@ in mixture with other taxanes), it is necessary to know its final concentration (in raffinate or extract) for new definition of LMS' operational parameters. There are, basically, two ways to get this information: a) by experiments; b) by theoretical simulation. In this chapter, is presented the second form.

\subsection{Adsorption process modeling}

The modeling strategy chosen to represent the SMB process consisted of a dynamic modeling, in which each column was modeled individually by a general rate model. In order to obtain this mathematical model, some assumptions must be made: the flow rates are constant in each zone; the transversal cross section is constant for and through column; radial dispersion can be neglected; the axial dispersion coefficient is a function of solute and flow rate; the external mass transfer resistance is considered; solid phase is composed of 
small spheres of uniform radius; the mobile phase is a dilute solution, so that Henry's law can be used to describe the sorbate uptake; the pore diffusion model describes the intraparticle transport mechanism; no chemical reaction occurs; initial concentration inside the column is zero. Based on the previous hypotheses, the adsorption process can be described by the following set of equations, for each solute in each column (Cremasco et al. 2009a, Cremasco \& Starquit, 2010).

Solid Phase

$$
\begin{gathered}
\varepsilon_{\mathrm{p}} \frac{\partial \mathrm{q}_{\mathrm{j}}^{\mathrm{k}}}{\partial \mathrm{t}}+\left(1-\varepsilon_{\mathrm{p}}\right) \frac{\partial \mathrm{C}_{\mathrm{p}_{\mathrm{j}}}^{\mathrm{k}}}{\partial \mathrm{t}}=\varepsilon_{\mathrm{p}} \mathrm{D}_{\mathrm{p}_{\mathrm{j}}} \frac{1}{\mathrm{r}^{2}}\left(\mathrm{r}^{2} \frac{\partial \mathrm{q}_{\mathrm{j}}^{\mathrm{k}}}{\partial \mathrm{r}}\right) \\
\mathrm{C}_{\mathrm{p}_{\mathrm{j}}}^{\mathrm{k}}=\mathrm{k}_{\mathrm{p}_{\mathrm{j}}} \mathrm{q}_{\mathrm{j}}^{\mathrm{k}}
\end{gathered}
$$

$q_{j}$ is the solute $j$ concentration in the liquid phase inside the particle pores (volume fraction $\left.\varepsilon_{p}\right), C_{p}$ is the solute concentration on the solid (volume fraction 1- $\varepsilon_{p}$ ), and indices $k$ and $j$ refer to solute and column, respectively. The initial and boundary conditions for solid phase are

$$
\begin{gathered}
\mathrm{t}=0 ; \mathrm{q}_{\mathrm{j}}^{\mathrm{k}}=\mathrm{q}_{\mathrm{j}}^{\mathrm{k}}(0, \mathrm{r}) \\
\mathrm{r}=0 ; \frac{\partial \mathrm{q}_{\mathrm{j}}^{\mathrm{k}}}{\partial \mathrm{r}}=0 \\
\mathrm{r}=\mathrm{R} ; \varepsilon_{\mathrm{p}} \mathrm{D}_{\mathrm{p}_{\mathrm{j}}} \frac{\partial \mathrm{q}_{\mathrm{j}}^{\mathrm{k}}}{\partial \mathrm{r}}=\mathrm{k}_{\mathrm{f}_{\mathrm{j}}}^{\mathrm{k}}\left(\mathrm{C}_{\mathrm{j}}^{\mathrm{k}}-\left.\mathrm{q}_{\mathrm{j}}^{\mathrm{k}}\right|_{\mathrm{r}=\mathrm{R}}\right)
\end{gathered}
$$

Fluid Phase

$$
\frac{\partial C_{j}^{k}}{\partial t}=E_{b_{j}}^{k} \frac{\partial^{2} C_{j}^{k}}{\partial z^{2}}-u^{k} \frac{\partial C_{j}^{k}}{\partial z}-\psi \frac{6 k_{f_{j}}^{k}}{d_{p}}\left(C_{j}^{k}-\left.q_{j}^{k}\right|_{r=R}\right)
$$

$C_{j}$ is the solute $j$ concentration in the fluid phase (volume fraction $\varepsilon$ ). The initial and boundary conditions for fluid phase are

$$
\begin{gathered}
t=0 ; C_{j}^{k}=C_{j}^{k}(0, z) \\
z=0 ; E_{b_{j}}^{k} \frac{\partial C_{i}^{k}}{\partial z}=u^{k}\left(C_{j}^{k}-C_{0_{j}}^{k}\right) \\
z=L ; \frac{\partial C_{j}^{k}}{\partial z}=0
\end{gathered}
$$

\section{Taxol $^{\circledR}$ separation case}

The Taxol ${ }^{\circledR}$ separation simulation is based on laboratory-scale, four-column SMB founded in the Cremasco et al. (2009a, 2009b) as shown in Figure 4. Each column presents the same 


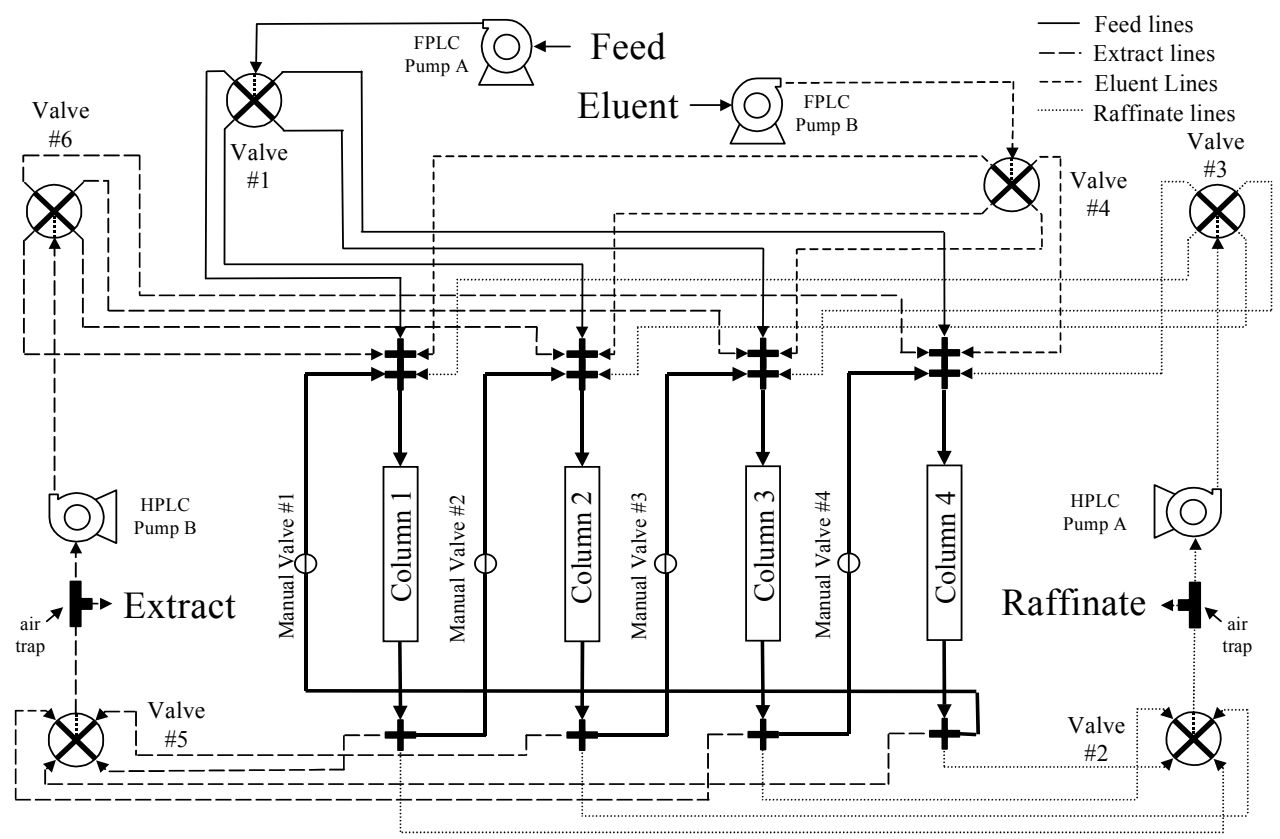

Fig. 4. SMB apparatus: valves system (Cremasco et al. 2009a, 2009b)

characteristics which are presented in Table 1. The system utilizes six eight-port rotary valves, four manual shut-off valves, and four pumps. The six rotary valves together determine the placement of the zones. Valve 1 determines where the feed enters (the column in zone I). Valve 2 determines where the raffinate is drawn. Valve 3 determines where the stream returns after the raffinate is drawn. Valve 4 determines where the desorbent enters. Valve 5 determines where the extract outlet occurs. Valve 6 determines where the recycle stream returns after the extract is drawn. The four manual shut-off valves provide a direct connection between consecutive columns when needed, and are closed to prevent back-flow when not needed. The four pumps consist of two Pharmacia LPLC pumps and two Waters HPLC pumps. The LPLC pumps provide the feed and desorbent flows. The HPLC pumps provide the recycle flow within the circuit. The raffinate pump (HPLC Pump A) provides the flow to Zone IV. The extract pump (HPLC Pump B) provides the flow to Zone II. The combined flow of the raffinate and desorbent pumps determines the flow rate of Zone I. The combined flow of the extract and feed pumps determines the flow rate of Zone III. The raffinate outlet flow rate is determined by the difference in the Zone III flow rate and the raffinate pump flow rate (Cremasco et al., 2009a).

\begin{tabular}{ccccccc}
\hline $\mathrm{D}_{\mathrm{b}}(\mathrm{cm})$ & $\mathrm{L}(\mathrm{cm})$ & $\mathrm{V}_{0}(\mathrm{ml})$ & $\varepsilon$ & & $\varepsilon_{\mathrm{p}}$ & $\mathrm{d}_{\mathrm{p}}(\mathrm{cm})$ \\
\hline 1.5 & 12.3 & 2.0 & 0.32 & 0.46 & 0.024 \\
\hline
\end{tabular}

Table 1. Column and particle characteristics (Cremasco et al., 2009a)

The solution was formed by Taxol ${ }^{\circledR}$ and three impurities, named $\operatorname{Tr} 10, \operatorname{Tr} 18$, and $\operatorname{Tr} 21$, based on their retention times in the HPLC chromatogram. Taxol ${ }^{\circledR}$ had a retention time of $12 \mathrm{~min}$. 
The physical parameters are presented in Table 2, while the initial concentrations of the species are summarized in Table 3.

\begin{tabular}{lcccc}
\hline Taxanes & Tr10 & Taxol & Tr18 & Tr21 \\
\hline$k_{p}(-)$ & 82.52 & 40.03 & 38.67 & 15.09 \\
$D_{A B}\left(10^{4} \mathrm{~cm}^{2} / \mathrm{min}\right)$ & 2.569 & 2.560 & 2.564 & 2.526 \\
$D_{p}\left(10^{4} \mathrm{~cm}^{2} / \mathrm{min}\right)$ & 1.310 & 0.590 & 0.920 & 0.384 \\
\hline
\end{tabular}

Table 2. Taxanes partition and diffusion coefficients (Cremasco et al., 2000a)

\begin{tabular}{cccc}
\hline$C_{\text {Taxol }}^{F}(\mathrm{ppm})$ & $C_{\text {Tr18 }}^{F}(\mathrm{ppm})$ & $C_{\text {Tr21 }}^{F}(\mathrm{ppm})$ & $C_{\text {Tr10 }}^{F}(\mathrm{ppm})$ \\
\hline 120.8 & 19.6 & 192.3 & 14.4 \\
\hline
\end{tabular}

Table 3. Feed composition and SMB operating parameters for Run 1

\section{Results and discussion}

\subsection{Run 1. Impurity separation that presents higher affinity with adsorbent}

Following the standing wave strategy to get the SMB operational parameters, we have:

Step 1. Column and particle characteristics: Table 1.

Step 2. Partition coefficient $k_{p}$ : Table 2 . In this case, less-retained mixture A (less affinity with adsorbent): $i=1=\operatorname{Tr} 21 ; i=2=\operatorname{Tr} 18 ; i=j=\operatorname{Taxol}^{\circledR}$; more-retained mixture B (high with adsorbent): $i=j+1=N=\operatorname{Tr} 10$.

Step 3. Mass transfer parameters: Table 2 for $D_{A B}$ and $D_{p}$. The convective mass transfer coefficient is calculated by (Wilson \& Geankoplis, 1966)

$$
\mathrm{Sh}_{\mathrm{j}}^{\mathrm{k}}=\frac{1.09}{\varepsilon}\left(\mathrm{Pe}_{\mathrm{MP}}^{1 / 3}\right)_{\mathrm{j}}^{\mathrm{k}}
$$

with Sherwood number and molecular mass Peclet number for a particle defined by, respectively,

$$
\begin{gathered}
\mathrm{Sh}_{\mathrm{j}}^{\mathrm{k}}=\frac{\mathrm{k}_{\mathrm{f}_{\mathrm{j}}}^{\mathrm{k}} \mathrm{d}_{\mathrm{p}}}{\mathrm{D}_{\mathrm{AB}}} \\
\mathrm{Pe}_{\mathrm{MP}}^{\mathrm{k}}=\frac{\mathrm{u}^{\mathrm{k}} \mathrm{d}_{\mathrm{p}}}{\mathrm{D}_{\mathrm{AB}}}
\end{gathered}
$$

and the axial dispersion coefficient calculated from (Chung \& Wen, 1968),

$$
\frac{\mathrm{E}_{\mathrm{b}_{\mathrm{j}}}^{\mathrm{k}}}{\mathrm{D}_{\mathrm{AB}_{\mathrm{j}}}}=\frac{\varepsilon P \mathrm{Pe}_{\mathrm{j}}^{\mathrm{k}}}{0.2+0.0011\left(\operatorname{Re}_{\mathrm{p}}^{\mathrm{k}}\right)^{0,48}}
$$

with particle Reynolds Number in zone k from 


$$
\operatorname{Re}_{p}^{k}=\frac{u^{k} d_{p}}{v_{B}}
$$

Step 4. From Table 3 and considering step 2: $C_{A}^{F}=322.7$ ppm; $C_{B}^{F}=14.4$ ppm.

Step 5. $\quad \mathrm{Y}_{\mathrm{A}}^{\mathrm{mix}}=0.999 ; \mathrm{Y}_{\mathrm{B}}^{\mathrm{mix}}=0.999$.

Step 6. $\mathrm{F}=0.10 \mathrm{ml} / \mathrm{min}$ (initial).

Step 11. After iterations in steps 6 up to 10, the operations parameters for Run 1 are presented in Table 4.

\begin{tabular}{ccccccccc}
\hline $\begin{array}{c}\mathrm{F} \\
(\mathrm{ml} / \mathrm{min})\end{array}$ & $\begin{array}{c}\mathrm{D} \\
(\mathrm{ml} / \mathrm{min})\end{array}$ & $\begin{array}{c}\mathrm{R} \\
(\mathrm{ml} / \mathrm{min})\end{array}$ & $\begin{array}{c}\mathrm{E} \\
(\mathrm{ml} / \mathrm{min})\end{array}$ & $\begin{array}{c}\mathrm{Q}^{\mathrm{I}} \\
(\mathrm{ml} / \mathrm{min})\end{array}$ & $\begin{array}{c}\mathrm{Q}^{\mathrm{II}} \\
(\mathrm{ml} / \mathrm{min})\end{array}$ & $\begin{array}{c}\mathrm{Q}^{\mathrm{III}} \\
(\mathrm{ml} / \mathrm{min})\end{array}$ & $\begin{array}{c}\mathrm{Q}^{\mathrm{IV}} \\
(\mathrm{ml} / \mathrm{min})\end{array}$ & $\begin{array}{c}\mathrm{t}_{\mathrm{p}} \\
(\mathrm{min})\end{array}$ \\
\hline 0.506 & 2.068 & 1.403 & 1.171 & 2.437 & 1.267 & 1.779 & 0.370 & 320.6 \\
\hline
\end{tabular}

Table 4. Operational parameters for Run 1

Step 12. Adsorption process modeling. The numerical solution of the mass-balance equations, Eqs. 28 and 33, are obtained from VERSE-LC code (VErsatile Reaction Separation simulator for adsorption and Liquid Chromatography processes), developed at Bioseparation Laboratory, School of Chemical Engineering, Purdue University, with base on numerical code founded in Whitley (1990). The simulations are based on a detailed model and numerical solution of the model equations. These equations are formulated based on mass conservation principles and fundamental constitutive relations, and are discretized using orthogonal collocation on finite elements, and the DASPK solver is used in the time domain (Whitley, 1990; Berninger et al., 1991). This numerical method has been used in the studies of many adsorption systems (Ma et al., 1996; Ernest et al., 1997; Koh et al., 1998, Cremasco et al., 2001).

The characteristics of column and particle adsorbent are presented in Table 1. The intrinsic parameters (isotherms and diffusivities coefficients) are listed in Table 2, and the convective mass transfer coefficient and axial dispersion coefficient are given by Eqs. (37) and (40), respectively. Simulated curves of solutes concentration distribution along mass-transfer at the cyclic-steady state, for Run 1, are presented in Figure 5. This figure shows that adsorption wave of Tr21 lies between zones II and III, adsorption waves of Taxol ${ }^{\circledR}$ and Tr18 are, basically, in zone III, while the Tr10 adsorption wave lies in zone IV. The Tr21 desorption wave lies between zones III and IV, and desorption waves of Taxol ${ }^{\circledR}$ and Tr18 are between zones I and IV, while Tr10 desorption wave lies in zone I.

The computational elution curves for raffinate and extract are presented in Figure 6 and 7, respectively. These curves are based on the average product concentration, in which each data point was at end of each port switching time $t_{p}$. The species concentrations at end of the Run 1, for raffinate port as well as extract port, are from steady-state regime. The concentration values, in this case, are shown in Table 5. It is possible to see in this table that Taxol $^{\circledR}$ is present in high concentration at raffinate port with $35.9 \%$ purity. However, in the raffinate is recovered the mixture A with $99.8 \%$ purity. In this case, the next separation step (Run 2) is considered a mixture as that one presents in Table 6, in which the focus is to separate the impurity Tr21. 


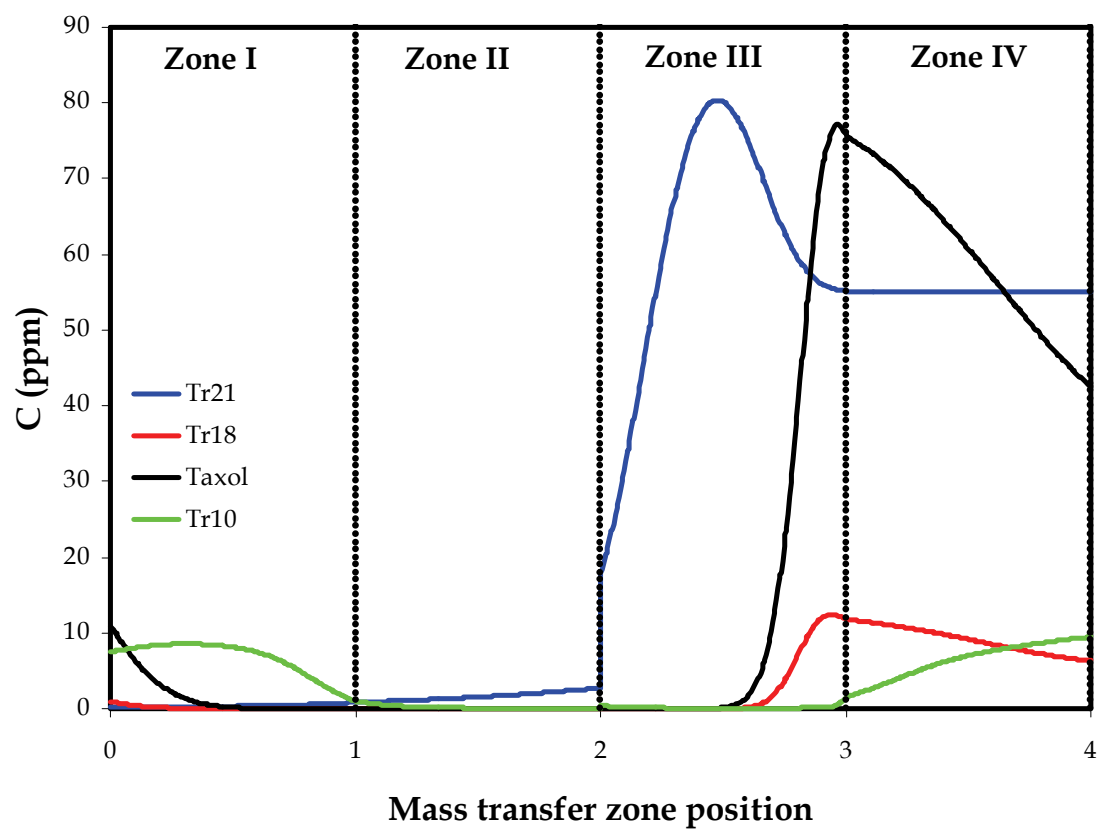

Fig. 5. Simulated curves of solutes concentration distribution along mass-transfer at the cyclic-steady state for Run 1

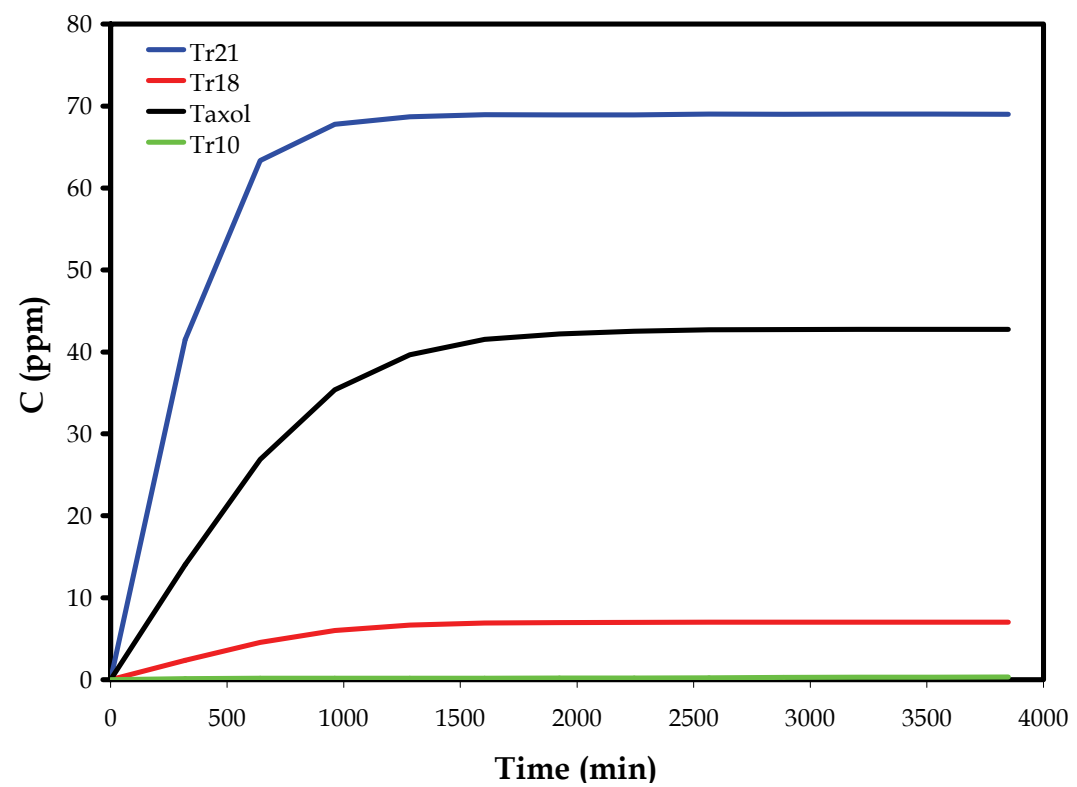

Fig. 6. Theoretical elution curves at raffinate port: Run 1 


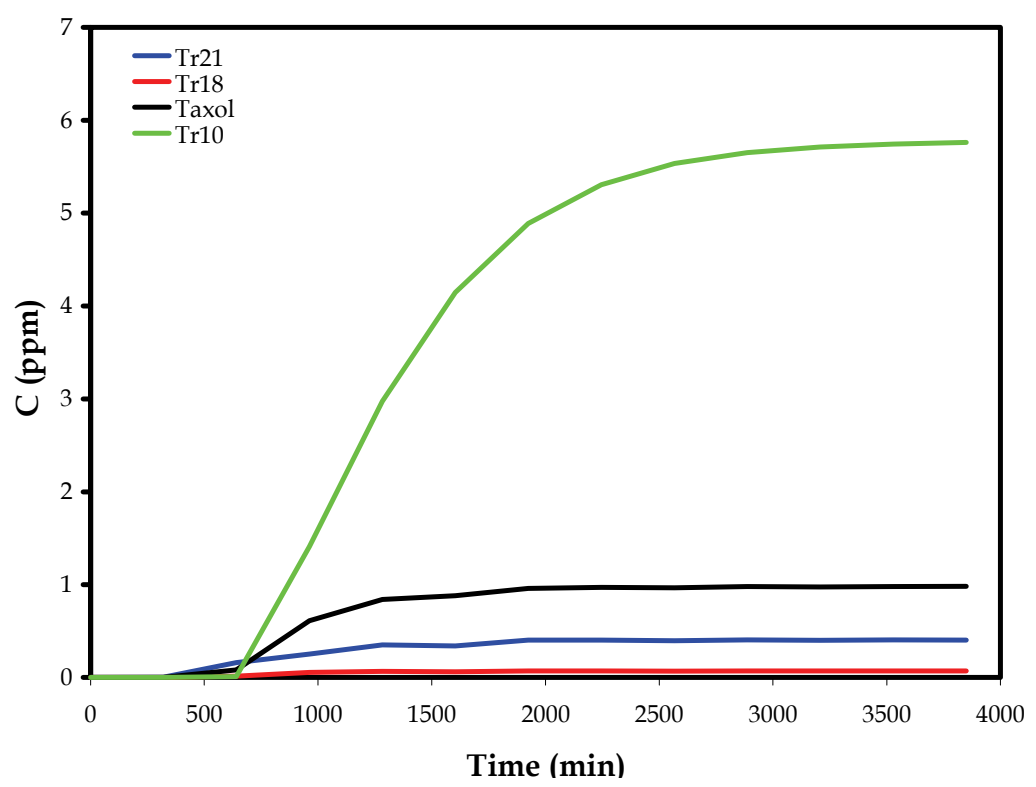

Fig. 7. Theoretical elution curves at extract port: Run 1

\begin{tabular}{ccccc}
\hline & $\begin{array}{c}\mathrm{C}_{\operatorname{Tr} 21} \\
(\mathrm{ppm})\end{array}$ & $\begin{array}{c}\mathrm{C}_{\text {Tr18 }} \\
(\mathrm{ppm})\end{array}$ & $\begin{array}{c}\mathrm{C}_{\text {Taxol }} \\
(\mathrm{ppm})\end{array}$ & $\begin{array}{c}\mathrm{C}_{\text {Tr10 }} \\
(\mathrm{ppm})\end{array}$ \\
\hline Raffinate & 69.00 & 7.01 & 42.74 & 0.33 \\
Extract & 0.40 & 0.07 & 0.98 & 5.76 \\
\hline
\end{tabular}

Table 5. Feed composition and SMB operating parameters for Run 2

\begin{tabular}{ccc}
\hline$C_{\text {Taxol }}^{F}(\mathrm{ppm})$ & $C_{\text {Tr18 }}^{F}(\mathrm{ppm})$ & $C_{\text {Tr21 }}^{F}(\mathrm{ppm})$ \\
\hline 42.74 & 7.01 & 69.00 \\
\hline
\end{tabular}

Table 6. Species concentration at steady-state regime for Run 1

\subsection{Run 2. Impurity separation that presents less affinity with adsorbent}

The same way for Run 1, we have:

Step 1. Same of Run 1.

Step 2. Partition coefficient $k_{p}$ : Table 2 . In this case, less-retained mixture A (less affinity with adsorbent): $i=1=j=\operatorname{Tr} 21$; more-retained mixture B (high with adsorbent) $i=$ $j+1=\operatorname{Tr} 18 ; i=N=$ Taxol ${ }^{\Theta}$;

Step 3. Same of Run 1.

Step 4. From Table 3 and considering step 2: $C_{A}^{F}=69.00$ ppm; $C_{B}^{F}=49.75$ ppm.

Step 5. $\mathrm{Y}_{\mathrm{A}}^{\mathrm{mix}}=0.9999 \mathrm{Y}_{\mathrm{B}}^{\mathrm{mix}}=0.9999$.

Step 6. $\mathrm{F}=0.10 \mathrm{ml} / \mathrm{min}$ (initial).

Step 11. After iterations in steps 6 up to 10, the operations parameters for Run 2 are presented in Table 7. 


\begin{tabular}{ccccccccc}
\hline $\begin{array}{c}\mathrm{F} \\
(\mathrm{ml} / \mathrm{min})\end{array}$ & $\begin{array}{c}\mathrm{D} \\
(\mathrm{ml} / \mathrm{min})\end{array}$ & $\begin{array}{c}\mathrm{R} \\
(\mathrm{ml} / \mathrm{min})\end{array}$ & $\begin{array}{c}\mathrm{E} \\
(\mathrm{ml} / \mathrm{min})\end{array}$ & $\begin{array}{c}\mathrm{Q}^{\mathrm{I}} \\
(\mathrm{ml} / \mathrm{min})\end{array}$ & $\begin{array}{c}\mathrm{Q}^{\mathrm{II}} \\
(\mathrm{ml} / \mathrm{min})\end{array}$ & $\begin{array}{c}\mathrm{Q}^{\mathrm{III}} \\
(\mathrm{ml} / \mathrm{min})\end{array}$ & $\begin{array}{c}\mathrm{Q}^{\mathrm{IV}} \\
(\mathrm{ml} / \mathrm{min})\end{array}$ & $\begin{array}{c}\mathrm{t}_{\mathrm{p}} \\
(\mathrm{min})\end{array}$ \\
\hline 0.439 & 1.557 & 0.663 & 1.333 & 2.073 & 0.740 & 1.179 & 0.516 & 215.3 \\
\hline
\end{tabular}

Table 7. Operational parameters for Run 2

Step 12. Adsorption process modeling. Same of Run 1.

Simulated curves of solutes concentration distribution along mass-transfer at the cyclicsteady state, for Run 2, are presented in Figure 8. This figure showed that TR 21 adsorption wave is, basically, in zone III, and its desorption wave is in zone I and IV. For Tr18 and Taxol ${ }^{\circledR}$, the adsorption waves are between zones I and IV, and their desorption wave are in zone II.

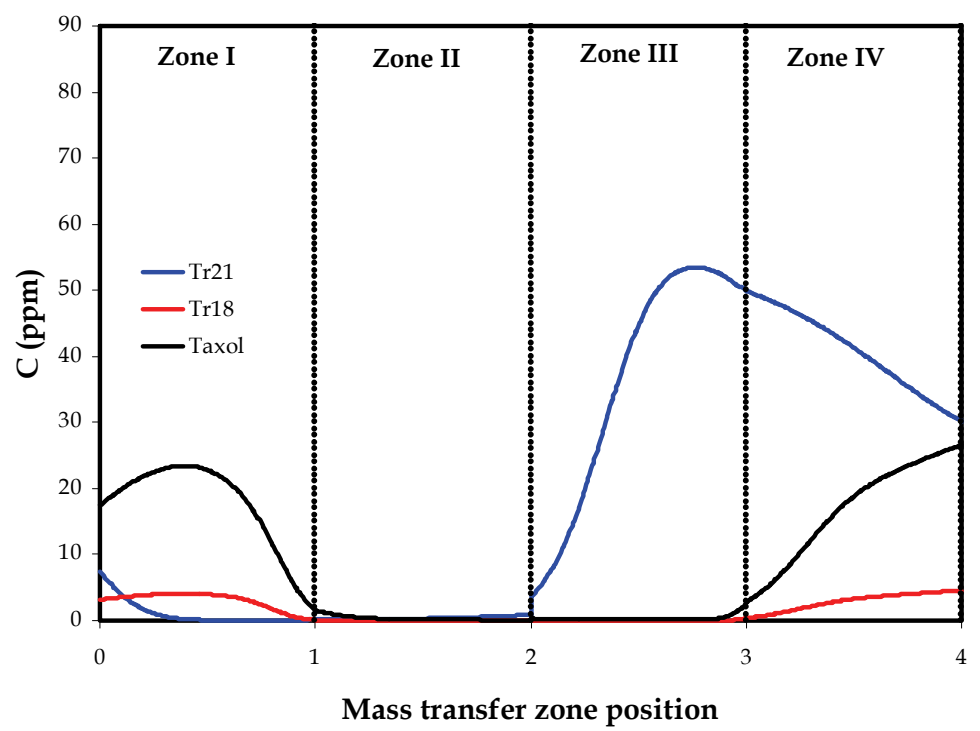

Fig. 8. Simulated curves of solutes concentration distribution along mass-transfer at the cyclic-steady state for Run 2

The computational elution curves for raffinate and extract are presented in Figure 9 and 10, respectively. These curves are based on the average product concentration, in which each data point was at end of each port switching time $t_{p}$. The species concentrations at end of the Run 2, for raffinate port as well as extract port, are from steady-state regime. The concentration values, in this case, are shown in Table 8 . From this table, there is recover of $93.3 \%$ purity of mixture B with. However, the Taxol ${ }^{\circledR}$ presents $83 \%$ purity.

\begin{tabular}{cccc}
\hline & $\mathrm{C}_{\operatorname{Tr} 21}$ & $\mathrm{C}_{\operatorname{Tr} 18}$ & $\mathrm{C}_{\text {Taxol }}$ \\
$(\mathrm{ppm})$ & $(\mathrm{ppm})$ & $(\mathrm{ppm})$ \\
\hline Raffinate & 43.50 & 0.05 & 0.50 \\
Extract & 0.53 & 2.21 & 13.33 \\
\hline
\end{tabular}

Table 8. Species concentration at steady-state regime for Run 1 


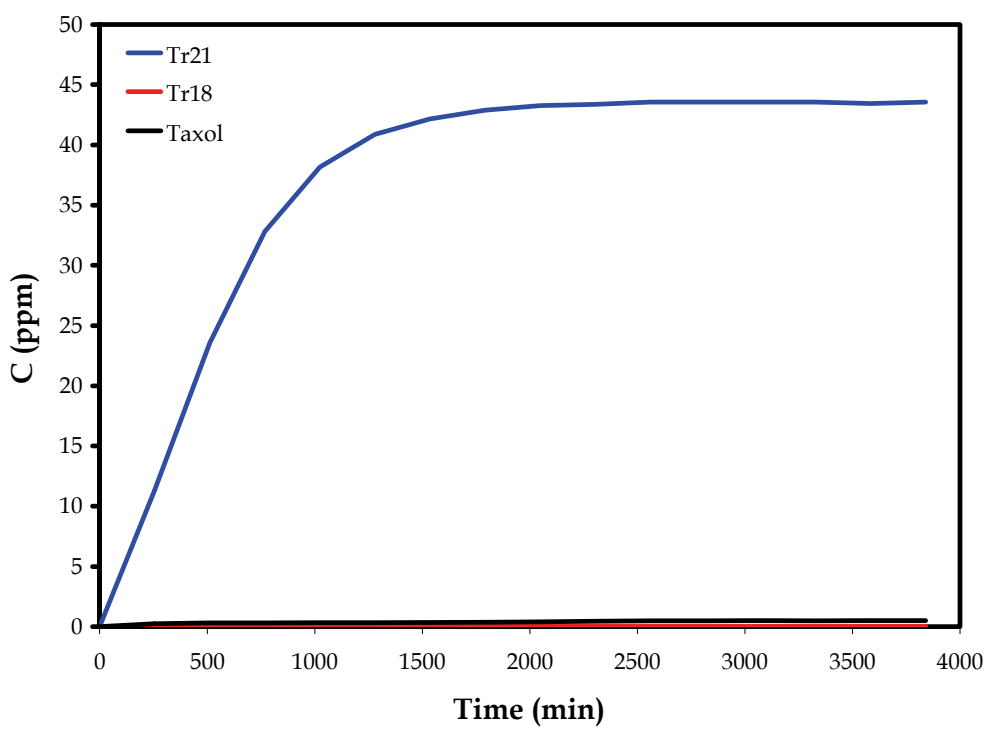

Fig. 9. Theoretical elution curves at raffinate port: Run 2

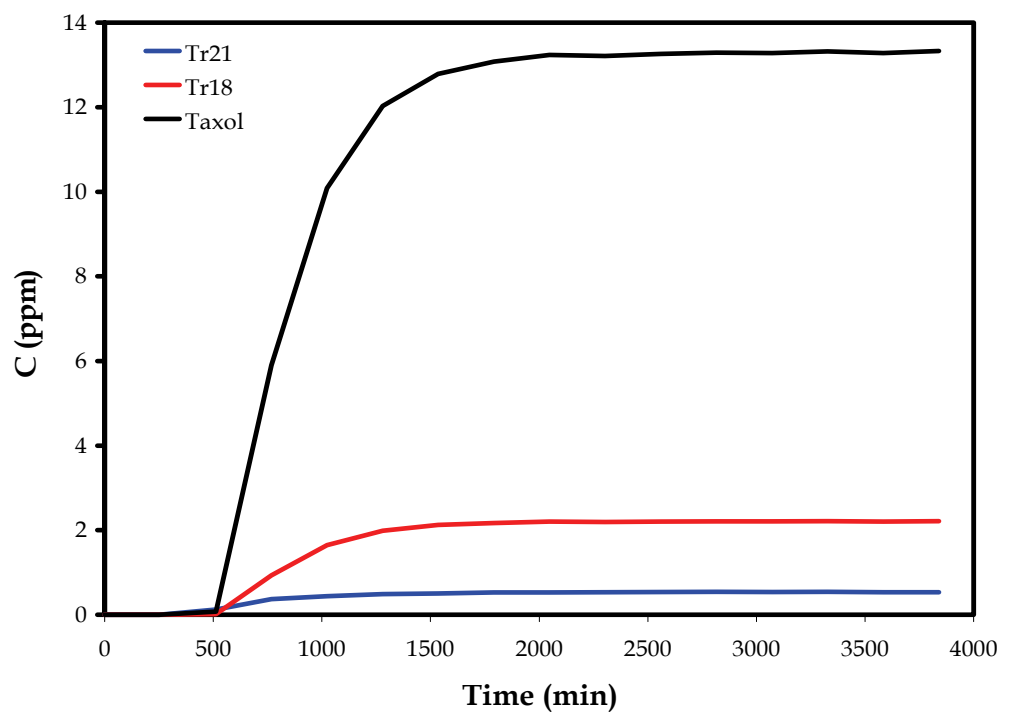

Fig. 10. Theoretical elution curves at extract port: Run 2

\begin{tabular}{ccc}
\hline$C_{\text {Taxol }}^{F}(\mathrm{ppm})$ & $C_{\text {Tr18 }}^{F}(\mathrm{ppm})$ & $C_{\text {Tr21 }}^{F}(\mathrm{ppm})$ \\
\hline 42.74 & 7.01 & 69.00 \\
\hline
\end{tabular}

Table 9. Feed composition and SMB operating parameters for Run 2 


\subsection{Run 2 - Alternative: SMB with eight columns}

With the goal to increase the Taxol ${ }^{\circledR}$ purity, it is possible to simulate the performance of experimental system, now, with eight columns, considering two columns in each mass transfer zone. The standing wave analysis strategy (SWA) is basically the same presented before; the difference is to consider $2 \mathrm{~L}$ instead $\mathrm{L}$ in the SWA model. After to apply the strategy presented in section 4.2, the operations parameters for Run 2 with eight columns are presented in Table 10.

\begin{tabular}{ccccccccc}
\hline $\begin{array}{c}\mathrm{F} \\
(\mathrm{ml} / \mathrm{min})\end{array}$ & $\begin{array}{c}\mathrm{D} \\
(\mathrm{ml} / \mathrm{min})\end{array}$ & $\begin{array}{c}\mathrm{R} \\
(\mathrm{ml} / \mathrm{min})\end{array}$ & $\begin{array}{c}\mathrm{E} \\
(\mathrm{ml} / \mathrm{min})\end{array}$ & $\begin{array}{c}\mathrm{Q}^{\mathrm{I}} \\
(\mathrm{ml} / \mathrm{min})\end{array}$ & $\begin{array}{c}\mathrm{Q}^{\mathrm{II}} \\
(\mathrm{ml} / \mathrm{min})\end{array}$ & $\begin{array}{c}\mathrm{Q}^{\mathrm{III}} \\
(\mathrm{ml} / \mathrm{min})\end{array}$ & $\begin{array}{c}\mathrm{Q}^{\mathrm{IV}} \\
(\mathrm{ml} / \mathrm{min})\end{array}$ & $\begin{array}{c}\mathrm{t}_{\mathrm{p}} \\
(\mathrm{min})\end{array}$ \\
\hline 0.758 & 2.635 & 1.144 & 2.250 & 3.512 & 1.262 & 2.020 & 0.877 & 126.3 \\
\hline
\end{tabular}

Table 10. Operational parameters for Run 2 with eight columns

Simulated curves of solutes concentration distribution along mass-transfer at the cyclicsteady state, for Run 2, with 8 columns, are presented in Figure 11. This figure showed basically the behavior founded in Run 2 with 4 columns: Tr21 adsorption wave is in zone III, and its desorption wave is in zone I and IV. For Tr18 and Taxol ${ }^{\circledR}$, the adsorption waves are in between zone I and IV, and their desorption waves are in zone II.

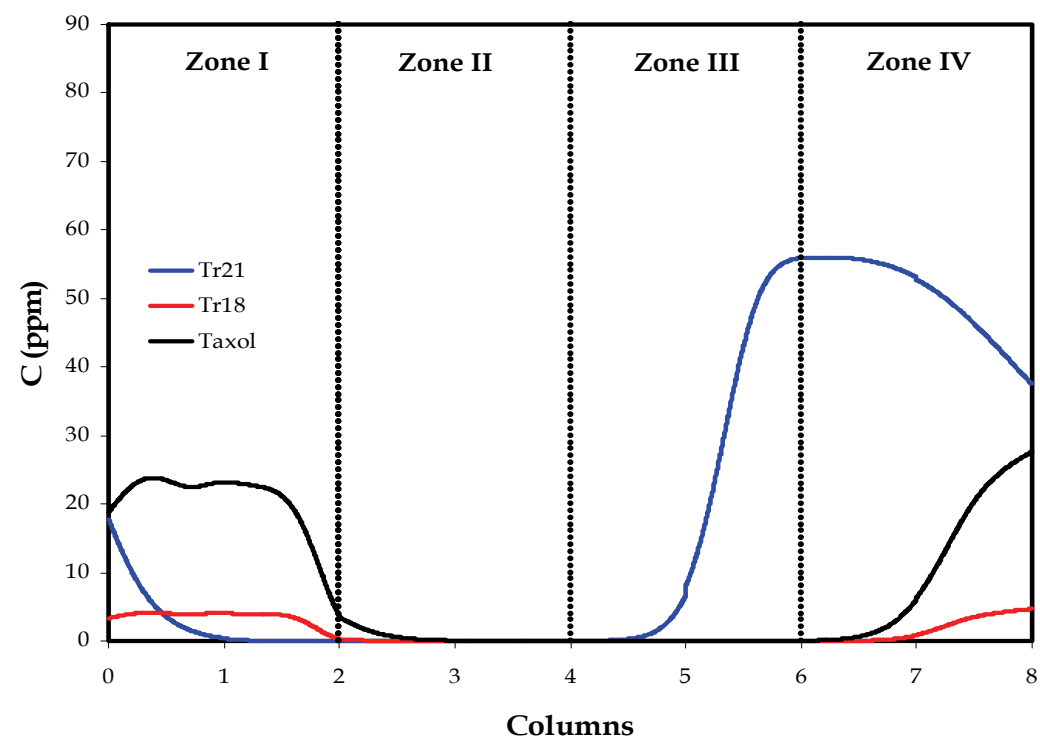

Fig. 11. Simulated curves of solutes concentration distribution along mass-transfer at the cyclic-steady state, for Run 2 with 8 columns

The computational elution curves for raffinate and extract are presented in Figure 12 and 13, respectively. These curves are based on the average product concentration, in which each data point was at end of each port switching time $t_{p}$. The species concentrations at end of the Run 2 with 8 columns, for raffinate port as well as extract port, are from steady-state regime. The concentration values, in this case, are shown in Table 11. 


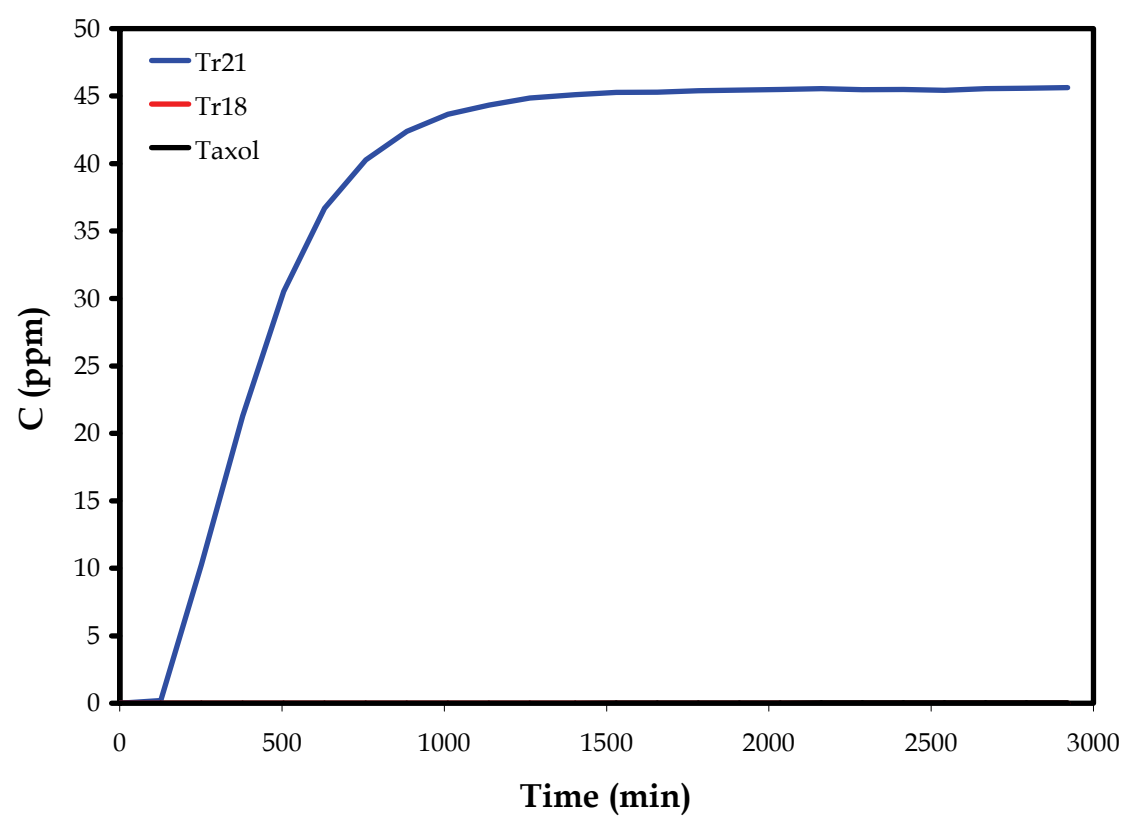

Fig. 12. Theoretical elution curves at raffinate port: Run 2

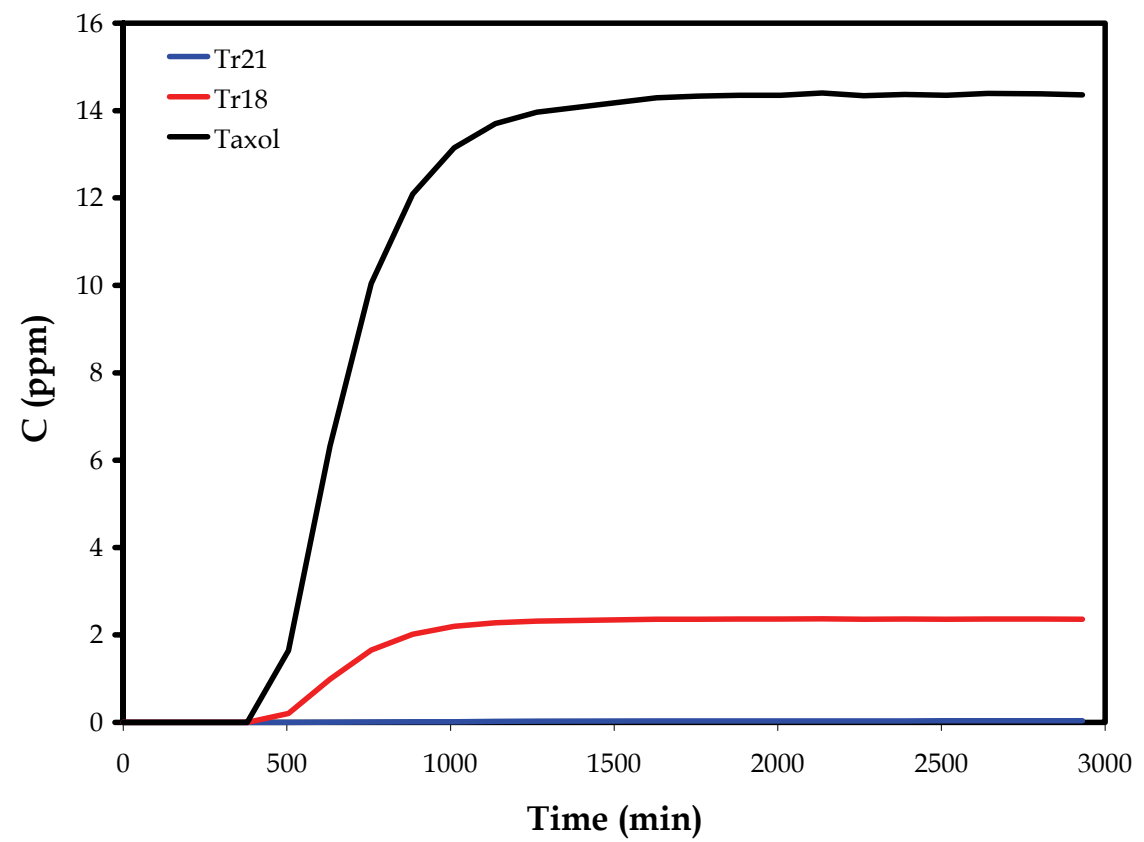

Fig. 13. Theoretical elution curves at extract port: Run 2 


\begin{tabular}{cccc}
\hline & $\begin{array}{c}\mathrm{C}_{\text {Tr21 }} \\
(\mathrm{ppm})\end{array}$ & $\begin{array}{c}\mathrm{C}_{\operatorname{Tr} 18} \\
(\mathrm{ppm})\end{array}$ & $\begin{array}{c}\mathrm{C}_{\text {Taxol }} \\
(\mathrm{ppm})\end{array}$ \\
\hline Raffinate & 45.63 & 0.00 & 0.03 \\
Extract & 0.03 & 2.36 & 14.38 \\
\hline
\end{tabular}

Table 11. Species concentration at steady-state regime for Run 2 with eight columns

Figure 12 shows that after switching ten times the valves position. Tr21 is already reaching the cyclic steady-state at raffinate port, with concentration showed in Table 11. In the other hands, the extract port is characterized by Taxol ${ }^{\circledR}$ (Figure 13). From Table 11, there is recover of $99.8 \%$ purity of mixture B. However, the Taxol ${ }^{\circledR}$ presents $85.7 \%$ purity. Despite on the increase of mixture B purity with columns number increase, the improvement of Taxol ${ }^{\circledR}$ purity is not relevant. In fact, Taxol ${ }^{\circledR}$ and Tr18 are difficult to separate using the chosen adsorbent, because the selectivity between the two solutes is close to one $\left(\alpha_{\text {Taxol }, \operatorname{Tr} 18}=k_{\text {Taxol }} / k_{\operatorname{Tr} 18}=1.035\right)$.

\section{Conclusion}

This chapter showed that a multicomponent and complex system, such as taxane mixture, can be treated as a pseudo-binary model, in which mixtures A (low-affinity mixture) and B (high-affinity mixture) are considered as single solutes A and B. In this case, it is possible to use the standing wave design to specify zone flow rates and switching time. The numerical simulation of SMB offers predictive results, pointing to two separation steps of Taxol ${ }^{\circledR}$ from impurities at least. It was analyzed the influence of column numbers in Taxol $^{\circledR}$ separation, in which purity improvement was not relevant with number-ofcolumn increase (4 to 8 ). In this case, the purity increase is governed by the selectivity between Taxol ${ }^{\circledR}$ and other solute.

\section{Acknowledgment}

The author acknowledges the financial support obtained from CNPq (Proc. n. 01/08101-3) for this research project.

\section{Nomenclature}

A - cross sectional column area; $\quad \mathrm{L}^{2}$

C - solute concentration in the mobile phase; $\mathrm{ML}^{3}$

$\mathrm{C}_{\mathrm{p}}$ - superficial solid intra-particle concentration; $\mathrm{ML}^{3}$

$\mathrm{C}_{0} \quad$ - column injection concentration; $\mathrm{ML}^{-3}$

D - eluent (desorbent) flow rate; L

$\mathrm{D}_{\mathrm{b}} \quad$ - column diameter; L

$\mathrm{D}_{\mathrm{AB}} \quad$ - free diffusion coefficient; $\quad \mathrm{L}^{2} \mathrm{~T}^{-1}$

$\mathrm{d}_{\mathrm{p}} \quad$ - average particle diameter; $\quad \mathrm{L}$

$\mathrm{D}_{\mathrm{p}} \quad$ - effective diffusion coefficient; $\quad \mathrm{L}^{2} \mathrm{~T}^{-1}$

E - extract flow rate; $\quad \mathrm{L}^{3} \mathrm{~T}^{-1}$ 


$\begin{array}{lll}E_{b} & \text { - axial dispersion coefficient; } & \mathrm{LT}^{2} \mathrm{~T}^{-1} \\ F & \text { - feed flow rate; } & \mathrm{L}^{3} \mathrm{~T}^{-1} \\ k_{f} & \text { - film mass transfer coefficient; } & \mathrm{LT}^{-1} \\ 1 / K_{f} & \text { - global mass transfer resistance; } & \mathrm{T} \\ k_{\mathrm{p}} & \text { - equilibrium partition constant; } & - \\ \mathrm{L} & \text { - zone length; } & \mathrm{L} \\ \mathrm{q} & \text { - intra-particle liquid phase concentration; } & \mathrm{ML}^{-3} \\ Q & \text { - zone flow rate; } & \mathrm{L}^{3} \mathrm{~T}^{-1} \\ \mathrm{R} & \text { - raffinate flow rate; } & \mathrm{LT}^{3} \mathrm{~T}^{-1} \\ \mathrm{R} & \text { - average particle radius; } & \mathrm{L}^{-} \\ t_{p} & \text { - switching period; } & \mathrm{T} \\ t_{0} & \text { - dead time; } & \mathrm{T} \\ \mathrm{u} & \text { - SMB liquid superficial velocity; } & \mathrm{LT}^{-1} \\ \mathrm{~V} & \text { - apparent adsorbent simulated velocity; } & \mathrm{LT}^{-1} \\ V_{0} & \text { - dead volume; } & \mathrm{L}^{3} \\ \mathrm{Y} & \text { - recovery. } & -\end{array}$

\section{Greek letters}

$\beta \quad$ - mass transfer correction in the standing wave analysis;

$\delta \quad$ - adsorption velocity;

$\varepsilon \quad$ - bed porosity;

$\varepsilon_{\mathrm{p}} \quad$ - particle porosity;

$\Psi \quad$ - bed porosity ratio.

\section{Subscripts}

$\begin{array}{ll}\text { A } & \text { - pseudo-solute A (low-affinity); } \\ \text { B } & \text { - pseudo-solute B (high-affinity); } \\ \text { D } & \text { - desorbent; } \\ \text { E } & \text { - extract; } \\ \text { F } & \text { - feed; } \\ \text { j } & \text { - specie j; } \\ \text { k } & \text { - mass transfer zone k; } \\ \text { R } & \text { - raffinate; } \\ \text { I, II, III, IV } & \text { - mass transfer zones I, II, III, IV. }\end{array}$

\section{Superscripts}

E - extract;

F - feed;

k - mass transfer zone k;

max - maximum value;

$\mathrm{R} \quad$ - raffinate;

I, II, III, IV - mass transfer zones I, II, III, IV. 


\section{References}

Berninger, J. A.; Whitley, R. D., Zhang, X., and L. Wang, N.-H. (1991), A versatile model for simulation of reaction and nonequilibrium dynamics in multicomponent fixed-bed adsorption processes, Comput. Chem. Eng., 15, 749-768.

Bonadonna, G. (1990), Does chemotherapy fulfill its expectation in cancer treatment?, Ann. Oncol., 1, 11-21.

Borges da Silva, A. A., Ulson de Souza, A. A., Rodrigues, A. E.; Ulson de Souza, and S. M. A. (2006), Glucose isomerization in simulated moving bed reactor by Glucose isomerase, Brazilian Arch. Biol., 49 (3), 491 - 502.

Chung, S. F., and Wen, C. Y. (1968), Longitudinal dispersion of liquid flowing through fixed and fluidized beds, AIChE J, 14, 857-866.

Cremasco, M. A., and Wang, N.-H. L. (2000), Ternary separation of amino acid in simulated moving bed, Part I: design strategy, Proceedings of XIV Chilean Chem. Eng. Meeting, CD ROM, Santiago, Chile.

Cremasco, M. A., Wu, D.-J., and Wang, N.-H. L. (2000), Estimation of partition coefficient and mass-transfer parameters of taxanes, (in Portuguese) Proceedings of XIII Brazilian Chem. Eng. Meeting, CD ROM, Aguas de São Pedro, Brazil.

Cremasco, M.A., Hritzko, B.J., Xie, Y., and Wang, N.-H. L. (2001), Parameters estimation for amino acids adsorption in a fixed bed by moment analysis, Brazilian J. Chem. Eng., 18 (2), 207-218.

Cremasco, M.A., Hritzko, B.J., and Wang, N.-H. L. (2009a), Experimental purification of paclitaxel from a complex mixture of taxanes using a simulated moving bed, Brazilian J. Chem. Eng., 26 (1), 207-218.

Cremasco, M.A., Starquit, A., and Wang, N.-H. L. (2009b), Separation of L-tryptophan present is an aromatic amino acids mixture in a four-columns simulated moving bed: experimental and simulation studies, Brazilian J. Chem. Eng., 26 (3), 611-618.

Cremasco, M. A., and Starquit, A. (2010), Modeling for Taxol ${ }^{\circledR}$ separation in simulated moving bed, Brazilian Arch. Biol., 53 (6), 1433 - 1441.

Ernest, M .V. Jr., R. D. Whitley, Z. Ma, and Wang, L. N.-H. (1997), Effect of mass action equilibria on fixed bed multicomponent ion exchange dynamics, Ind. Eng. Chem. Res., 36, 212-226.

Holanda, C. M. C. X., Oliveira, H. E., Rocha, L. G., Spyrides, M. H. C., Aragão, C. F. S., and Medeiros, A. C. (2008), Effect of Paclitaxel $\left(\right.$ Taxol $\left.^{\circledR}\right)$ on the biodistribution of sodium pertechnetate $\left(\mathrm{Na}^{99} \mathrm{mTCO}_{4}\right)$ in female wistar rats, Brazilian Arch. Biol., 51 (Special number), 191 - 196.

Koh, J-H., Wankat, P.C., and Wang, L. N.-H. (1998), Pore and surface diffusion and bulkphase mass transfer in packed and fluidized beds, Ind. Eng. Chem. Res., 37, 228-239.

Ma, Z.; R.D Whitley, R. D., and Wang, L. N.-H. (1996), Pore and surface diffusion in multicomponent adsorption and liquid chromatography systems, AIChE J., 42 (5), 1244-1262.

Ma, Z., and Wang, N.-H. L. (1997), Standing wave analysis of SMB chromatography: linear systems, AIChE J., 43, 2488-2507.

Rhoads, D.N. (1995), The recovery of Taxol from plant tissue culture media, BSc Thesis, Purdue University, West Lafayette, USA. 
Srinivasan, V., Pestchanker, L., Moser, S., Hirasuna, T.J., Taticek, R., and Shuler, M.L., (1994), Taxol production in bioreactors: Kinetics of biomass accumulation, nutrient uptake, and Taxol production by cell suspensions of Taxus baccata, Biotechnol. Bioeng., 47, 666-676.

Whitley, R. D. (1990), Dynamics of nonlinear multicomponent bhromatography - Interplay of mass transfer, intrinsic sorption kinetics, and reaction, Ph. D. Thesis, Purdue University, West Lafayette, USA.

Wilson, E.J., and Geankoplis, C.J. (1966), Liquid mass transfer at very low Reynolds numbers in packed beds, Ind. Eng. Chem. Fundam., 5, 9-14.

Wu, D.-J, Ma, Z., Au, B.W. , and Wang, N.-H, L. (1997), Recovery and purification of Paclitaxel using low-pressure liquid chromatography, AIChE J., 3 (1), 232-242.

Wu, D-J. (1999), Development of simulated moving bed chromatography processes for biochemical purification, Ph. D. Thesis, Purdue University, West Lafayette, USA. 


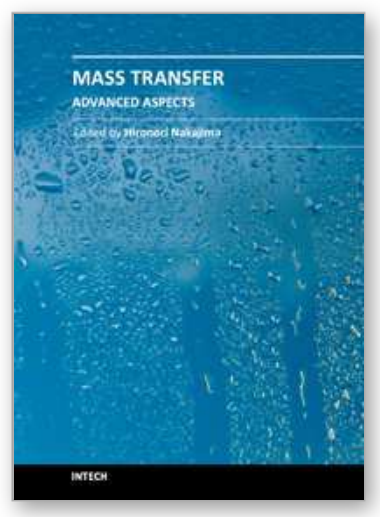

\author{
Mass Transfer - Advanced Aspects \\ Edited by Dr. Hironori Nakajima
}

ISBN 978-953-307-636-2

Hard cover, 824 pages

Publisher InTech

Published online 07, July, 2011

Published in print edition July, 2011

Our knowledge of mass transfer processes has been extended and applied to various fields of science and engineering including industrial and manufacturing processes in recent years. Since mass transfer is a primordial phenomenon, it plays a key role in the scientific researches and fields of mechanical, energy, environmental, materials, bio, and chemical engineering. In this book, energetic authors provide present advances in scientific findings and technologies, and develop new theoretical models concerning mass transfer. This book brings valuable references for researchers and engineers working in the variety of mass transfer sciences and related fields. Since the constitutive topics cover the advances in broad research areas, the topics will be mutually stimulus and informative to the researchers and engineers in different areas.

\title{
How to reference
}

In order to correctly reference this scholarly work, feel free to copy and paste the following:

Marco Aurelio Cremasco (2011). Taxol® Separation in a Simulated Moving Bed, Mass Transfer - Advanced Aspects, Dr. Hironori Nakajima (Ed.), ISBN: 978-953-307-636-2, InTech, Available from:

http://www.intechopen.com/books/mass-transfer-advanced-aspects/taxol-separation-in-a-simulated-movingbed

\section{INTECH}

open science | open minds

\section{InTech Europe}

University Campus STeP Ri

Slavka Krautzeka 83/A

51000 Rijeka, Croatia

Phone: +385 (51) 770447

Fax: +385 (51) 686166

www.intechopen.com

\section{InTech China}

Unit 405, Office Block, Hotel Equatorial Shanghai

No.65, Yan An Road (West), Shanghai, 200040, China

中国上海市延安西路65号上海国际贵都大饭店办公楼 405 单元

Phone: +86-21-62489820

Fax: $+86-21-62489821$ 
(C) 2011 The Author(s). Licensee IntechOpen. This is an open access article distributed under the terms of the Creative Commons Attribution 3.0 License, which permits unrestricted use, distribution, and reproduction in any medium, provided the original work is properly cited. 